\title{
Determinants of Market Participation of Smallholder Sorghum Farmers and Strategies for Improving Their Participation; the Case of Moretna Jiru District, Ethiopia
}

\section{Atinkugn Assefa Belete ( $\sim$ Atinkugn20@gmail.com )}

College of Business and Economics, Samara University

Research

Keywords: Small holder, Market participation, Probit, Moretna jiru, Ethiopia

Posted Date: December 15th, 2020

DOl: https://doi.org/10.21203/rs.3.rs-126144/v1

License: (c) (i) This work is licensed under a Creative Commons Attribution 4.0 International License.

Read Full License 


\title{
Determinants of Market Participation of Smallholder Sorghum Farmers and Strategies for Improving Their Participation; the Case of Moretna Jiru District, Ethiopia
}

\author{
Atinkugn Assefa Belete ${ }^{1 *}$
}

${ }^{1}$ Department of Economics, College of Business and Economics, Samara University, P.O.Box 132, Semera, Ethiopia.

*Corresponding author: Ainkugn20@gmail.com +251919864243, P.O.Box 132

\begin{abstract}
The purpose of this study is to identify market participation of smallholder's Sorghum producers in Moretna jiru district, central Ethiopia. Primary data was collected from 355 randomly selected smallholder farm households from three randomly selected kebeles in the district. The survey data was analyzed using descriptive statistics and econometrics model with probit and Tobit censored model. Results of the probit model analysis showed that output, farm size, extension contact and ownership of transport positive and significant role in households' decision to participate in sorghum output sales at $1 \%$ level of significance; whereas, household income, off-farm income, access to credit and lack of information negatively at $1 \%$ and $10 \%$ level of significance. Results of Tobit censored analysis showed; extension contact, farm size, output and membership of farmer group have positive and significant role in the value of sorghum at $1 \%$ level of significance; while access to credit was found to have negative significant role at $5 \%$ level of significance. Farm size, output, extension contact and membership of farmer group was found to affect both households' decisions to participate and intensity of participation in sorghum sales at 1\% level of significance. Based on the findings there is a need to enhance the interaction between extension export and farmers and distribute trained extension exports in all kebeles by giving different trainings. ; and help the farmers improve land productivity, where possible, by intensifying farm practices through provision of sustainable and timely availability of inputs and management practices so as to generate surplus sorghum output and boost sales.
\end{abstract}

Keywords: Small holder, Market participation, Probit, Moretna jiru, Ethiopia 


\section{Introduction}

Agriculture has been playing significant role in the development of nation's economy for centuries. It contributes to development as livelihood, as an economic activity, and as a provider of environmental services, making the sector a unique instrument for development (World Bank, 2007).

Agriculture is a source of livelihoods for an estimated 86 percent of rural people. It create job for 1.3 billion smallholders and landless workers, "farm-financed social welfare" when there are

urban shocks, and a foundation for viable rural communities. In the developing world from 5.5 billion people, 3 billion live in rural areas, nearly half of humanity. Of these rural inhabitants an estimated 2.5 billion are in households involved in agriculture, and 1.5 billion are in smallholder households. Globally it employs more than $40 \%$ of the active labor force (Benjamin et al., 2014; World Bank, 2007).

As an economic activity, agriculture helps the rural poor to achieve food security because majority of them derive their incomes from agricultural production. Specially, this contribution becomes powerful/basic in the case of Sub-Saharan Africa where majority of the people experience highly variable domestic production, limited tradability of food staples and foreign exchange constraints.

In Sub-Sahara Africa (SSA) the majority of the population lives in rural areas where poverty and deprivation is severe. It is estimated that about 70 percent of the rural poor in SSA depend on agriculture for their livelihood directly or indirectly (IFAD, 2011).Therefore, any poverty reducing strategies that focus on agriculture are more effective than other sectors in poverty alleviation. Poverty reduction strategies focusing on agriculture directly raise farm incomes by increasing marketable output and indirectly through generating employment as agriculture is labour-intensive. The agricultural sector also has linkages with other sectors such as processing industries and factor markets (Pender and Alemu, 2007).

Promoting commercialization of agricultural production is a cornerstone of the rural development and poverty reduction strategies of Ethiopia, as well as numerous other developing countries. Policymakers in Ethiopia and elsewhere view agricultural commercialization as an essential part of the process of agricultural modernization, specialization, and structural 
transformation of the economy toward more rapid and sustainable growth (Pender and Alemu, 2007).

Ethiopia seeks growth that is poverty reducing and agricultural growth is seen as the key to deliver broad-based growth in rural areas (where the vast majority of the poor live) and reduce Rural poverty. The government has formulated a development strategy commonly known as ADLI1 to implement this policy objective. A series of institutional and policy reforms were undertaken (since the early 1990s) to enhance agricultural production and stabilize the macroeconomic environment. The government followed its ADLI strategy by decreeing a series of policies seeking to generate: (i) a more supportive macroeconomic framework; (ii) liberalized markets for agricultural products; and (iii) a strong extension- and credit-led push for intensification of food staples production through the use of modern inputs, especially seed and fertilizer. These early reforms focused on cereals and provided a much needed boost to agricultural production.

Locking in to sorghum crop, Sorghum is the $5^{\text {th }}$ most important cereal crop globally, after maize, wheat, rice and barley with annual production of over 60 million tonnes (www.fao.org) and an important food grain crop in the semi-arid tropics. Sorghum is a critical food security crop for more than 100 million people in Africa. It predominantly grows in low-rainfall, arid to semiarid environments due to its excellent tolerance to drought, high temperature stresses and low soil fertility (Doggett, 1988).

In Ethiopia, sorghum is one of the most important staple cereal crops after tef and maize. It account for about 14.6, next to $24,16.8$ tef and maize respectively to the total cereal crop cultivated area (CSA, 2014).Ethiopia is the second largest sorghum producer in Africa, after the Sudan and In Ethiopian agriculture sorghum grasps the third largest share of total cereal production (Mekonnen Demeke and Di Marcantonio, 2013).

In rural part of Moretna jiru special district sorghum is the most important and amiable crop in terms of productivity and making friendly relationship to the weather condition and soil type. Because Sorghum is drought resistant and is grown well at low elevations where rainfall is less 
reliable. In the study area different crops are grown such as; sorghum, tef, bean, pea, barely, mung bean and vegetables but sorghum is the dominant crop in terms of area coverage as well as productivity. On the best of my knowledge there is no Study about identifying determinants of commercialization of smallholder sorghum production in Ethiopia and in the study area. Considering the resource limitation and the scope of the research, this study is aimed at to identify the level and determinants of smallholders' sorghum output market in Moretna jiru special district.

\subsection{Problem Statement /motivation}

In Ethiopia $85 \%$ of the people are farmers and they lives depends on agriculture. Agriculture in Ethiopia takes the lion's share of the economy. Its growth has stronger linkages or multiplier effect on the entire economy than the non-agricultural growth. But the farmer produce for family consumption due to natural, policy, health, land, economic, religious and other factors. Improving smallholder farmer's productivity and commercialization has a key solution in transforming Ethiopia's agriculture from subsistence to market oriented production or commercial agricultural production.

In Ethiopia, several policy papers regarding commercializing of the smallholder agriculture were prepared and implemented targeting the integration of smallholder farmers to markets like PASDEP. The papers set comprehensive objectives on the advancement of smallholder farmers' incorporation into domestic and international markets to improve their incomes (MOFED, 2006 and MoARD, 2010). Give more weight to the importance of transferring from a subsistencebased smallholder system to a stronger market-based orientation is the best mechanism to leave out smallholder farmers from substance life or vital points in the agricultural revolution process (Siziba. 2011).

Coming to sorghum, it is grown in a wide range of agro-ecologies, most importantly in highly moisture-stressed environments where other crops cannot survive. The north-eastern region of Ethiopia is known for its rich sorghum genetic diversity, mainly due to the agro-ecological and cultural diversity of the growers and consumers. Despite its huge potential in the region, sorghum productivity is well below the national and global average. It is widely produced as food crop (Beyene et al., 2016). 
Previous studies on sorghum in Ethiopia have much more concentrated on factors affecting adoption of improved sorghum, for example (Hailegebrial \& Adane, 2018; Tsfaye, 2013; Mahdi et al., 2012; Kinfe, 2018; Salih et al,. 2018; Beyene et al, .2016) and genetic diversity of sorghum, for example (Olani,2017; Mugambi,2010; Tesfaye,2017). But adoption of improved seed by itself is Band-Aid to boost farmer's income and food security. Here of, more study needs to fill this gap. Up to date, information on factors influencing the market participation/commertalization of producers in the sorghum market in Ethiopia is lacking. More over to the best of my knowledge nothing has been done in the study area as well as in Ethiopia.

Therefore, this study were to identify factors that influence smallholder sorghum farmers' participation decision and intensity of sorghum sales in the study area in order to fill the research gap and contributes to the generation of indication for policy makers to understand greater market participation of smallholder farmers in the area, Especially in Moret and Jiru district. This study will used as a source of literature for future researcher those who have interested to study market participation and others and Helps to design appropriate strategy for commercialization and boost sustainable economic development of smallholder farmers. 


\section{Research Methodology}

\subsection{Description of the Study Area}

This study was conducted in Amhara Regional State, north Shawa zone of Moretna Jiru district particularly in rural sorghum growing kebeles. Moretna Jiru (Amharic "Moret and Jiru") is one of the districts in the Amhara Region of Ethiopia. It is named in part after the historic district of Shawa, Moret, which lay between the Jamma River and the district of Shawa Meda. The coordinates for the study area are $39^{\circ} 19^{\prime} 24^{\prime \prime}$ E and $10^{\circ} 6^{\prime} 2^{\prime \prime} \mathrm{N}$ with an altitude ranges from 1,500 to $2694 \mathrm{~m}$ above sea level and receives an annual rainfall of 850 $\mathrm{mm}$ while the temperature varies from $5.2^{\circ} \mathrm{C}$ in November to $28.8^{\circ} \mathrm{C}$ (Kassa w. et al., 2017). Moretna jiru district is inhabited by a population of 110,927 of which 58,484 are males and 52,443 are females (CSA, 2015).

The district has a total area of 706 square Kilometer. More than 87 percent of this land is cultivable. The district has two distinct agro ecological conditions: (i) a highland plateau with annual average rainfall of about $900 \mathrm{~mm}$ and soil dominated by the vertisol type; and (ii) gorge (valley) areas with rugged topography, non-vertisol dominated soil, a less reliable rainfall pattern and higher temperatures. The farming system was characterized by mixed crop-livestock farming. Farmers produce different crop in order to safe their family food supply and also cover various household expenses. The production system in the study area can be described in two ways, i.e., rain-fed and irrigated systems. The rain-fed production system is most dominant and is practiced by the majority of the farmers in the study area.

The district has a total of 21 kebeles. From those 12 are rural and the remaining 2 kebeles, 7 kebeles are rural town, Dega kebeles (highland) respectively. The geography of the 12 Sorghum growing rural kebeles was similar. The study was focused only on rural part of Moretna jiru district due to accessibility of sorghum crop production. In all rural kebeles, sorghum is the dominant crop and cultural practices continue to be relatively traditional and draft animals are used for ploughing and cultivation. The sorghum crop was sown and harvested manually and chemical inputs including fertilizers are rarely used in all kebeles.

Figure 1: Map of The Study Area (Moretna jiru District) 


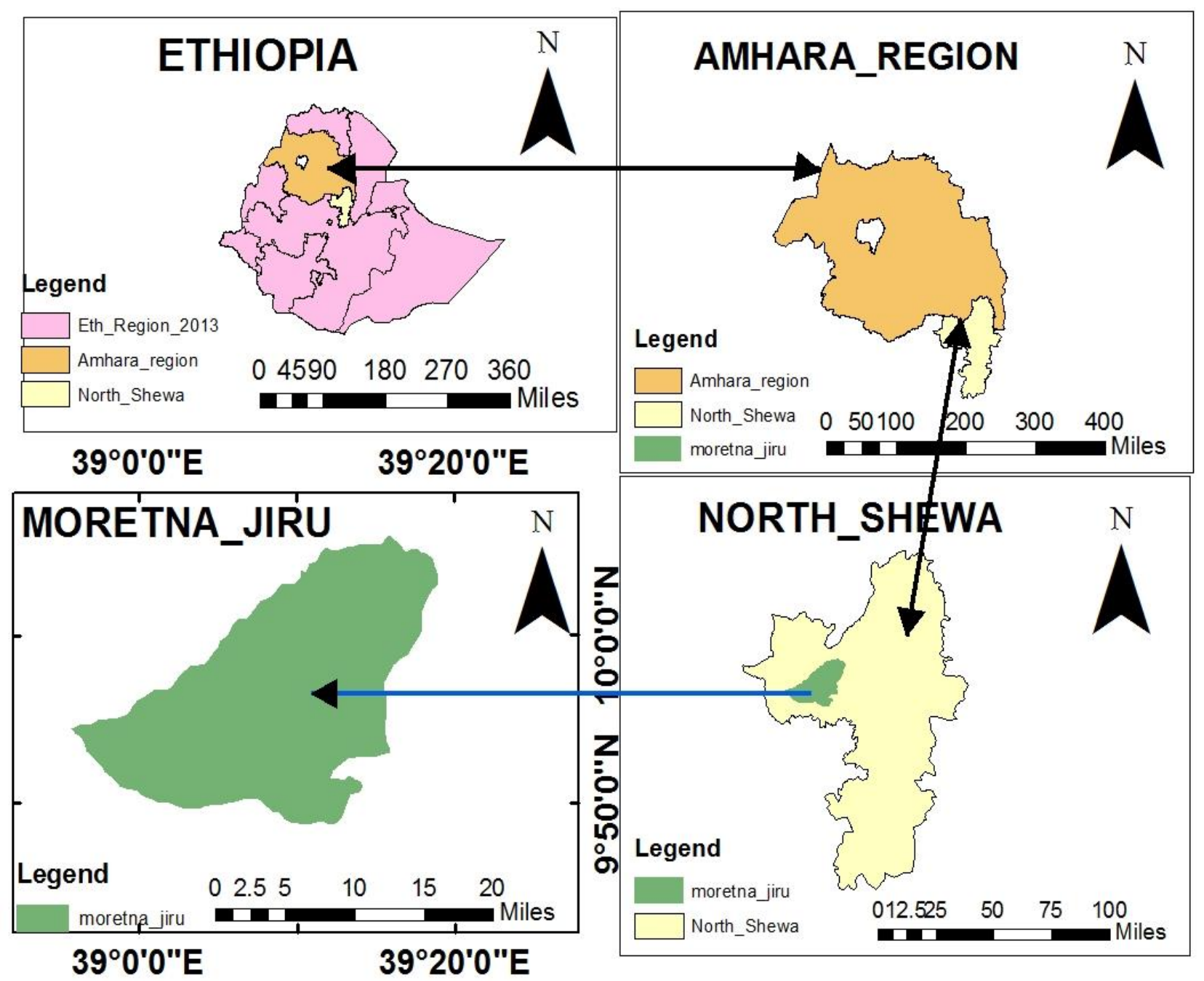

Data Source: MJDAO (2011)

\subsection{Sampling Technique and Sample Size Determination}

This study targeted smallholder farmers in Moretna jiru district of Ethiopia. A multistage sampling procedure was used to identify respondents for the study. In the first stage sorghum growing kebeles was identified in collaboration with the District's Agricultural Office from which three kebeles were selected randomly. These were Yewelo, yimedeb and lamwasha. Then from the selected three kebeles 355 sample were selected randomly based on probability proportionate to size of the kebeles' number of households. The number of sample households was determined using Yamane (1967)'s formula. 


$$
\begin{aligned}
& \mathrm{n}=\frac{N}{1+N\left(e^{2}\right)} \cdots \cdots \cdots \\
& \mathrm{n}=\frac{3120}{1+3120(0.05)^{2}}=355
\end{aligned}
$$

Where; $\mathrm{n}$ is sample size, $\mathrm{N}$ is the population size (total number of the households in three kebeles), e is acceptable margin of error (level of precision).

\subsection{Data Collection Method}

In this study both secondary and primary data were used. To collect primary data from the sample households a designed structured questionnaire interview schedule were employed. Cross sectional data collected from randomly sampled households were the major source of primary data used for this study. To facilitate the task of data collection, enumerators was employed from the study areas and they were trained. The structured questionnaire was designed to collect a range of data on amounts of sorghum production and the proportion sold output and household characteristics such as age, gender, marital status of the household head, household size.

Secondary data was also gained from reports of similar studies and information's documented at various office levels of Woreda agricultural office. Important literatures on market participation was also accessed from the internet, books, unpublished materials, journals, government publications, reports of international and regional organizations.

\subsection{Method of Data Analysis}

Descriptive and econometric methods were applied to analyze the data collected from smallholder household heads using structured questionnaire.

\subsubsection{Model Specification}

Econometric model was used to identify the factors that affect farmers 'decision on adoption of organic fertilizer and sorghum crop marketing. In this study the data have limited dependent variable nature. Most recent literature adopts "Tobit and Heckman's two step models' to identify factors that affect producers to participate on marketing of crops. Ideally, 
the Ordinary Least Square (OLS) model is applicable when all households participate in the market. In reality not all households participate in a specific commodity market. Some households may not prefer to participate in a particular market in favor of another, while others may be excluded by market conditions.

If the OLS regression is estimated excluding the non-participants from the analysis, a sample selectivity bias is introduced into $\boldsymbol{a}$ model. For this study to solve the above mentioned problem probit and censored Tobit model are appropriate. The outcome variable smalholder farmer participation on sorghum crop market were binary and analyzed/addressed with probit model whereas extent of sorghum market participation is censored at zero and analyzed by Tobit censored model. Hence, in this study Tobit censored model is appropriate to identify factors that affect the extent of sorghum market participation.

\section{Household's output market participation can be specified as}

Probit model was used to estimate the factors influencing market participation decision of sorghum growers in the study area. According Egbetokun and Omonona (2012), the probit model to analyze the farmers' decision to participate in the output market can be computed from the standard normal cumulative distribution function as follows:

$\mathrm{P}(0,1)=\mathrm{P}(\mathrm{y}=1 \mid \mathrm{x})=\mathrm{P}\left(\mathrm{Zi}^{*} \leq \mathrm{Z}\right)=\mathrm{P}\left(\mathrm{Zi}^{*} \leq \beta 1+\beta 2 \mathrm{xi}\right)=\mathrm{F}(\beta 1+\beta 2 \mathrm{xi})$

Where, $\mathrm{P}(0,1)$ or $\mathrm{P}(\mathrm{y}=1 \mid \mathrm{x})$ is the probability that an individual household participate in the market given the explanatory variables $\mathrm{Xi}$ hypothesized to affect farmers 'decision to participate in sorghum market and $\mathrm{Y}$ is a dependent variable which takes on the value of 1 if the farmers participate in the sorghum market and 0 otherwise. Thus, the model specification on the decision of whether to participate in the market or not can be estimated as follows:

$$
Z^{*}=X_{1 i} \beta_{1}+U_{1 i} ; U_{1 i} \approx N(0,1)
$$

\section{$\mathrm{Z}=\mathbf{1}$ if $\mathrm{Z}^{*}>\mathbf{0}$}

$\mathbf{Z}=\mathbf{0}$ if $\mathbf{Z}^{*} \leq \mathbf{0}$

Where:

$Z^{*}=$ is a dependent variable which takes on the value 1 if a household participates insorghum markets and 0 otherwise.

$\mathrm{X}_{\mathrm{i}}$ : are vectors of variables that are assumed to affect the probability of sampled household sorghum market participation 
$\beta_{1}$ : is a vector of unknown parameter in participation equation.

$\mathrm{U}_{1}: \quad$ are residuals that are independently and normally distributed with zero mean and constant variance.

Since the probit parameter estimate does not show by how much a particular variable increases or decreases the likelihood of participating in sorghum crop markets, marginal effects of independent variables on probability of a household to participate was considered. For continuous independent variables, marginal effect was calculated by multiplying coefficient estimate by standard probability density function by holding other independent variables at their mean values.

The marginal effect of dummy independent variables was analyzed by comparing probabilities of that result when the dummy variables take their two different values ( 1 if participated and 0 otherwise) while holding all other independent variables at their sample mean values (Wooldridge, 2002). The log likelihood function which is maximized to obtain parameter estimates and corresponding marginal effects is given as:

$\operatorname{Ln} L\left(\frac{b}{z}, X\right)=\sum_{z=1} \ln \left(\Phi(X, b)+\sum_{z=0} \ln (1-\Phi(X, b) \ldots \ldots \ldots \ldots \ldots \ldots \ldots\right.$ (3)

To analyze the factors affecting the level of market participation, Tobit regression model was chosen. This dependent variable is called the "censored dependent variable" or "dependent variable with ceiling effect" as the information on the dependent variable is available only for some observations (individuals). According to Gujarati (2004), the Heckman two stage models is the alternative to Tobit model but the estimates from Heckman model are consistent but not efficient as the estimates from the maximum likelihood of Tobit model. For the researcher data The Tobit regression models are attractive because of their ability to account for censoring in the dependent variable. Tobit model has been applied in many studies including (Martey, 2012) when determining the extent of market participation among cassava growers in Ghana.

The model specification on the extent of sorghum surplus participation can thus be estimated as follows: 
$\mathrm{Y}^{*}=\mathrm{B}_{0}+\sum_{i=1}^{m} B_{1} X_{i}+\mathrm{U}_{i} \quad \mathrm{i}=1,2,3 \ldots \ldots \ldots \ldots \ldots \ldots$

Where $\mathrm{Y}=\mathrm{Y}^{*}$, if $\mathrm{Y}^{*}>0$ and $\mathrm{Y}=0$ if $\mathrm{Y}^{*} \leq 0$ and $\mathrm{Y}=\max \left(\mathrm{Y}^{*}, 0\right)$

Where $\mathrm{Y}^{*}=$ market supply of sorghum (dependent variable)

$$
\begin{aligned}
& \beta 0=\text { an intercept } \\
& \beta \mathrm{i}=\text { coefficients of } \mathrm{ith} \text { independent variable (xi) } \\
& \mathrm{Xi}=\text { independent variable } \\
& \mathrm{Ui}=\text { unobserved disturbance term }
\end{aligned}
$$

Where, for the $\mathrm{i}^{\text {th }}$ observation, $\mathrm{Y}^{*}$ is an unobserved continuous latent variable, $\mathrm{Yi}$ is the observed variable, $\mathrm{Xi}$ is a vector of values on the independent variables, $\mathrm{Ui}$ is the error term, and $\beta \mathrm{i}$ is a vector of coefficients. This model assumes that $\mathrm{Ui}$ is uncorrelated with $\mathrm{Xi}$ and is independently and identically distributed. The model parameters are estimated by maximizing the likelihood function of the following form;

$$
\mathrm{L}=\prod_{y *>0} \frac{1}{\delta} \mathrm{f} \frac{\left(Y-B_{i}\right)}{\delta} \prod_{y *<0} F \frac{\left(-B_{i} X_{i}\right)}{\delta}
$$

Where $\mathrm{f}$ and $\mathrm{F}$ are respectively, the density function and cumulative distribution function of $\mathrm{Yi}^{*}, \pi y i^{*}>0$ implied the product over those observations for which $\mathrm{yi}^{*}>0$, and $\pi \mathrm{yi}{ }^{*} 0$ implied The product over those observations for which yi* 0 .

1. The marginal effect of an explanatory variable on the expected value of the Dependent variable as denoted by Maddala, G.S, (1983).

$\frac{\partial E\left(Y_{i}\right)}{\partial X_{i}}=\mathrm{F}(\mathrm{Z}) B_{i}$ where $\frac{B_{i X_{i}}}{\delta}$

Where $\mathrm{f}$ and $\mathrm{F}$ are respectively, the density function and cumulative distribution function of $\mathrm{Yi}^{*}, \pi \mathrm{yi}^{*}>0$ implied the product over those observations for which $\mathrm{yi}^{*}>0$, and $\pi \mathrm{yi}^{*}=0$ implied the product over those observations for which $\mathrm{yi}^{*}=0$.

2. The change in the probability of market participation as independent variable Xi Changes:

$$
\frac{\partial F(Z)}{\partial X_{i}}=f(z) \frac{B_{i}}{\partial}
$$


3. The change in intensity of value of quantity supplied with respect to a change in an explanatory variable among sellers:

$\frac{\partial E\left(\frac{Y_{i}>0}{Y *_{i}}\right)}{\partial X_{i}}=B_{1}\left[1-Z \frac{f(Z)}{F(Z)}-\left(\frac{f(Z) 2}{F(Z)}\right)\right]$

Where, F (z) is the Cumulative Normal Distribution of $\mathrm{z}, \mathrm{f}(\mathrm{z})$ is the value of the derivative of the normal curve at a given point (i.e., unit normal density), $\mathrm{z}$ is the $\mathrm{Z}$ score for the area under normal curve, $\beta \mathrm{i}$ is a vector of Tobit Maximum Likelihood estimates and $\sigma$ is the standard error. Estimation of the whole system of the supply function would give more efficient estimates, but excluding inconsistencies or biases.

Table 2.1 Definition and measurement of variables Used in Empirical Analysis

\begin{tabular}{|c|c|c|c|}
\hline \multirow{2}{*}{$\begin{array}{l}\text { Explanatory } \\
\text { Variables }\end{array}$} & \multirow{2}{*}{ Description } & \multirow{2}{*}{ Measurement } & hypothesis \\
\hline & & & $\begin{array}{l}\text { Market } \\
\text { participati } \\
\text { on }\end{array}$ \\
\hline Part & $\begin{array}{l}\text { Binary variable indicating } \\
\text { the decision to participate } \\
\text { in the output market as } \\
\text { sorghum sell or not }\end{array}$ & $\begin{array}{l}\text { Dummy: } 1=\text { farmer participates in market } \\
\text { (sold sorghum); } 0=\text { otherwise }\end{array}$ & \\
\hline HCL & $\begin{array}{l}\text { Proportional value of } \\
\text { sorghum sold to total crop } \\
\text { income }\end{array}$ & Household commertalization index & \\
\hline 1. $A G E$ & Age of the farmer & Number of year & $-/+$ \\
\hline 2. GEN & Gender of the farmer & Dummy: $1=$ if male; $0=$ otherwise & + \\
\hline 3. $E D U C$ & $\begin{array}{l}\text { Education level of the } \\
\text { household head }\end{array}$ & Number of years of schooling & + \\
\hline 4. MARST & Marital status of farmer & $\begin{array}{l}\text { categorical variable: } 1=\text { married; } 2= \\
\text { divorced, } 3=\text { widowed, } 4=\text { nun, } 5=\text { single }\end{array}$ & + \\
\hline 5. HHSIZE & Household size & Number of people in the household & - \\
\hline 6. $M F O$ & $\begin{array}{l}\text { Membership of farmer } \\
\text { group }\end{array}$ & Dummy: $1=$ if member; $0=$ otherwise & + \\
\hline 7. FRMSIZE & $\begin{array}{l}\text { Total land for sorghum } \\
\text { production season of } \\
2010 / 2011\end{array}$ & Hectares & + \\
\hline 8. HHINC & Total annual household & Ethiopian birr (ETB) & \\
\hline
\end{tabular}




\begin{tabular}{|c|c|c|c|}
\hline & income from crop & & + \\
\hline 9. OFINC & $\begin{array}{l}\text { Share of off farm income to total } \\
\text { income of HH. }\end{array}$ & Ratio & $+/-$ \\
\hline 10. OUTPUT & $\begin{array}{l}\text { Total output of sorghum } \\
\text { produced in the 2018/19 } \\
\text { production season }\end{array}$ & Number of in $\mathrm{kg}$ & + \\
\hline 11. ACCRE & Access to credit by farmer & $\begin{array}{c}\text { Dummy: } 1=\text { if farmer received } \\
\text { Credit; } 0=\text { otherwise }\end{array}$ & + \\
\hline 12. EXTCON & $\begin{array}{l}\text { Number of days farmer } \\
\text { contact with extension } \\
\text { officer }\end{array}$ & continuous (days of contact & + \\
\hline 13.OWNT & $\begin{array}{l}\text { owner means of } \\
\text { transportation }\end{array}$ & $\begin{array}{l}\text { Dummy: } 1=\text { ownership of Transportation; } \\
0=\text { otherwise }\end{array}$ & + \\
\hline 20.DISMK & $\begin{array}{l}\text { Distance to the nearest } \\
\text { market }\end{array}$ & kilometers & - \\
\hline 18. MKTINFO & $\begin{array}{l}\text { farmer access to market } \\
\text { information }\end{array}$ & $\begin{array}{l}\text { Dummy; } 1=\text { if yes } \\
0=\text { otherwise }\end{array}$ & + \\
\hline
\end{tabular}




\section{RESULTS AND DISCUSSION}

This result and discussion chapter is organized in to some main sections like: Describing socio-economic and demographic characteristics of sampled farming households in three kebeles in Moretna jiru district; major actors and their roles in market participation of small holder sorghum farmers.

\subsection{Comparison of Demographic and Socio-Economic Characteristics of sorghum farmers}

Table 3. 1: Comparison of key household level characteristics by Sorghum sellers (Sorghum market participation)

\begin{tabular}{|c|c|c|c|c|c|c|c|}
\hline \multicolumn{3}{|c|}{ Variables name } & \multicolumn{2}{|c|}{ Participant $(n=146)$} & \multicolumn{3}{|c|}{$\underline{\text { non-participant(n=209) }}$} \\
\hline & Mean & & SD & Mean & over: & 1 mean & t-test value \\
\hline age & 57.71 & 233 & .9069073 & 57.82297 & .6475452 & 57.77746 & 0.1021 \\
\hline HHsize & 7.30 & 08219.16 & .1665355 & 4.889952 & 0997408 & 5.884507 & $-13.1921 * * *$ \\
\hline farm size & 5.94 & $45205 \quad .12$ & .1255242 & 3.411483 & .0572762 & 4.453521 & $-20.2255 * * *$ \\
\hline \multicolumn{3}{|c|}{ Household income 29178.77} & 594.6536 & 26686.12 & 448.8722 & 27711.27 & $-3.4066 * * *$ \\
\hline Output & \multicolumn{2}{|r|}{24.39041} & .4832942 & 19.44019 & 9.3207887 & 21.47606 & $-8.8851 * * *$ \\
\hline \multicolumn{3}{|c|}{ Distance to market 3.407534} & .0388739 & 3.292823 & 3.0307215 & 3.34 & -2.3383 \\
\hline Extension & contact & 4.458904 & .1398855 & 2.559809 & .0754545 & 3.340845 & $-12.8594 * * *$ \\
\hline
\end{tabular}

Note, $* * *$, indicate significance at $1 \%$ probability level while SD Denotes standard deviation.

Source: survey data $(2010 / 11)$

\subsection{Gender and Marital status Distribution among sorghum crop farmers in} Moretna jiru special district. 
Figure 2: Source of Market Information

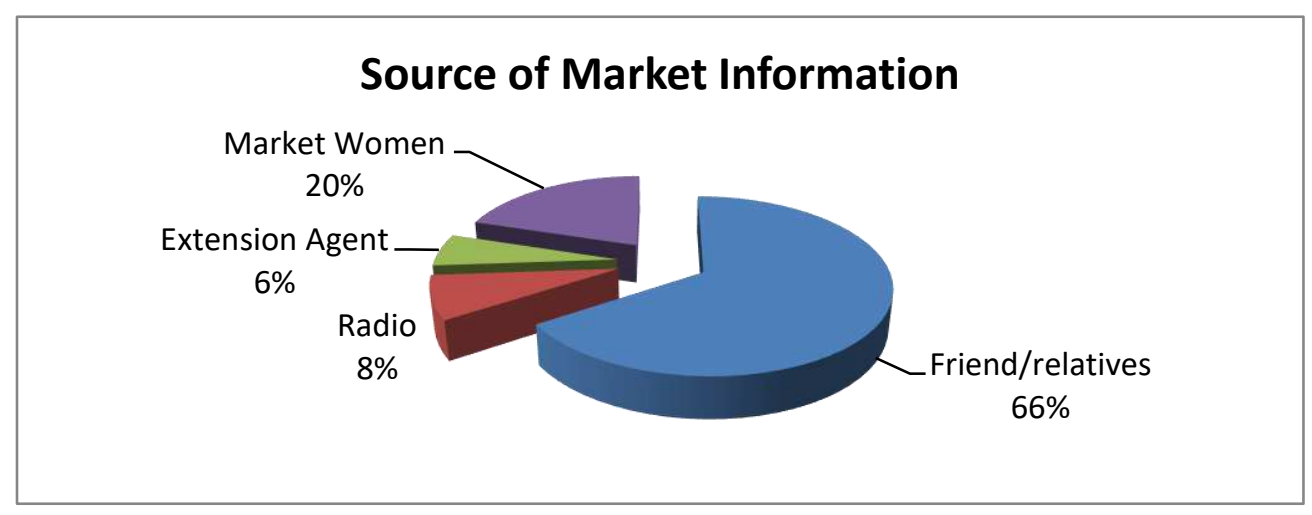

Source: Survey Data (2010/11)

\subsection{Determinants of Market Participation of Smallholder Farm Households}

The results for the determinants of market participation of sorghum crop producers (estimated by probit models) are shown in (Table 3.2). The Wald chi-square values of 196.60 are statistically significant at 1 percent significant level. This indicating that the explanatory variables explain the probability of participating in sorghum markets. It can be observed that the likelihood ratio statistics as indicated by chi-square are highly significant $(\mathrm{P}<0.0000)$, suggesting that all the model parameters were jointly significant in explaining the dependent variable. The pseudo R2 were 0.7556 suggesting that the specification fits the model well and the variables included in the model explain $75 \%$ of variation in the decision of market participation, indicating the goodness of fit of the model.

Table 3.2 presents the results of the probit model which analyses the factors that affect the farmers' decision to participate in sorghum crop market among farmers in Moretna jiru district. According to the results of the probit model, the most important factors that determine the small holder sorghum farmers' decision to participate in the supply of sorghum 
crop to the markets are identified and presented in (Table 3.2). The model was fitted with 15 variables and form those variable eight of them were significant. Such as: ownership of transport, quantity of sorghum produced, household income, off- farm income, market information, credit access, membership of farmer group, farm size and extension contact.

Output of sorghum: The probit results showed that 'sorghum quantity produced' had positive and significant effect on the household decision to participate in the sorghum market. The sign of the coefficient is positive and it means that if a farmer get much more production, the probability of taking a decision to participate in the output market increases. The marginal effect revealed that a unit measurement (quintal) increase in the sorghum quantity produced increased the probability of market participation by 3 percent. This study is in line with the findings of (Mather et al., 2011) higher outputs increase the likelihood of market participation because it enables households to have a marketable surplus.

This can be explained by the fact that sorghum is among the cash crops grown in Moretna jiru district; the higher the output the higher the farmers ${ }^{\text {ee }}$ motivation to sell more to generate more income. This study also in line with the findings of Pender (2007) who observed that increasing the production of food crops is the most significant factor that increases the crop sales in Ethiopia. Mussema (2012) also found that when farmers produce more pepper, they are more likely to participate in the output market.

Off-farm income: It was estimated that income from off-farm activities may have positive or negative effect on market participation because this income may strengthen the farming practice or may make the household unwilling to depend on sorghum production to get money. Therefore, as shown in (Table 3.2). The probit model result revealed that access to off-farm activities have a negative significant impact on the farmers' decisions to participate in the sorghum output market in the study area. This means that if farmers participate in alternative activities to farm-income source, they are less likely to involve in food production thereby reducing the household's position in crop market. The marginal effects of the survey data revealed that if a household involves in one alternative work or non-farm income source, the probability of market participation decreases by 23.6 percent. 
Market information: In relation to market information, the result shows that lack of access to market information has a negative effect on the probability to participate on surplus sorghum market and is statistically significant at 10 percent.

The marginal effect revealed that individual sample households who have no market information at all would reduce the probability of market participation by 19.5 percent as compared to individual sample households who obtain market information always. The negative sign of the coefficient indicated that lack of information about the market reduce the participation of small holder farmers in sorghum surplus market.

Household income: As expected, household income negatively and significantly influenced the likelihood of farmer's participation in sorghum market. Household heads with higher level of income are less likely to participate on sorghum output markets. The marginal effect of household income was 0.5362406 implying that a unit measurement increase in household income would decrease the probability of entering/participating in sorghum output market by 53.62 percent. The negative sign of this variable implies that if the farmers had additional income generating mechanism they did not wary about agriculture and they spend most of their time for another private business because agriculture is labor intensive and bulky (it needs a lot effort). 
Table 3.2 Probit Model Results for Factors Influencing Probability of Sorghum Sellers

\begin{tabular}{|c|c|c|c|}
\hline VARIABLES & Coefficient\&Std. Err. & Marginal e & effect \\
\hline Age & $(.0145631)$ & -.0058328 & $(.00539)$ \\
\hline Gender & $.7763755 * * \quad(.3689263)$ & $.2538383 * *$ & $(.1047)$ \\
\hline Educational Level & & & \\
\hline Read and Write_2 & $.0777813 \quad(.3597874)$ & 0289174 & $(.13544)$ \\
\hline Primary school & $-.0872779 \quad(.2864777)$ & -.0315787 & $(.10222)$ \\
\hline Extensation Contact & $.3870443 * * *(.0650764)$ & $.1424956^{* * *}$ & $(.02554)$ \\
\hline Market information & & & \\
\hline Some times_2 & $.2748771 \quad(.3340325)$ & .1026653 & (.12717) \\
\hline Not at all_3 & $-.542598 * \quad(.294976)$ & $-.195476^{*}$ & $(.10061)$ \\
\hline Ownership of Transportati & tion $.7248751^{*} \quad(.2928972)$ & $227788^{* * *}$ & $(.07885)$ \\
\hline 1Household Size & $.9198733^{*} \quad(.3856346)$ & $.3386639 * *$ & $(.13976)$ \\
\hline 1Farm Size & $2.700834 * * *(.5056446)$ & $.9943491 * * *$ & $(.17497)$ \\
\hline Credit Access & $-.667336 * * * \quad(.1945668)$ & $-.2398491 * * *$ & $(.06454)$ \\
\hline $\begin{array}{l}\text { OFF-Farm Income } \\
\text { Martial Statius }\end{array}$ & $-.6717112 * * * \quad(.1917342)$ & $-.2360979 * * *$ & $(.06716)$ \\
\hline Widowed_2 & $.3590317 \quad(.4393906)$ & .1372812 & $(.17092)$ \\
\hline Divorced_3 & $.83459^{*} \quad(.4012465)$ & .3232951 & $(.14846)$ \\
\hline 1Household Income & $-1.456528 * * *(.4831672)$ & $-.5362406^{* * *}$ & $=(.17483)$ \\
\hline 1Distance to the Market & $.3024368 \quad(1.115154)$ & .1113463 & $(.41155)$ \\
\hline Output & $.0823996 * * *(.023584)$ & $.0303366 * * *$ & $(.00869)$ \\
\hline Membership of farmer org & ganization $1.204876 * * *(.247148)$ & $.4125947 * * *$ & $(.06939)$ \\
\hline Constant & $5.271034 \quad(4.307651)$ & & \\
\hline
\end{tabular}

\begin{tabular}{clll}
\hline Robust standard errors in parentheses & \\
$* * * \mathrm{p}<0.01, * * \mathrm{p}<0.05, * \mathrm{p}<0.1$ & \\
Prob $>$ chi2 & 0.0000 & & \\
Log pseudolikelihood & -58.775594 & Number of obs & 355 \\
Wald chi2 (18) & 196.60 & Pseudo R2 & 0.7556 \\
\hline
\end{tabular}

Source: Survey Data (2010/11 


\section{4: Factors Influencing Intensity of Market Participation}

The Tobit censored model was used to analyze factors affecting intensity of market participation. From the (Table 3.3) it can be observed that the likelihood ratio statistics as shown by chi-square are highly significant $(\mathrm{P}<0.0000)$ suggesting that the model has strong explanatory power. Intensity of market participation was measured by quantity of sorghum sold (value).

Table 3.3 presents the variables that influence intensity of participation among sorghum farmers in Moretna jiru district. From 14 variables that were fitted for this study nine variables were significant. Such as: farm size size, quantity of sorghum produced.

Farm size had a positive and significant effect on the intensity of sorghum supplied to the market at probability level of $p=0.000$. The positive sign indicates that as the farm size increases the quantity marketed would be increased. This could be because having a big farm size increases the quantity of sorghum produced. For an extra unit of farm size would increase the value of sorghum to be sold by 6226.78 birr (Table 3.3).

The results in (Table 3.3) indicated that 'sorghum quantity produced' had positive significant influence on the extent of commercialization in the study area $(\mathrm{p}=0.055)$. The Tobit censored model results showed that the increase in sorghum output by one quintal increases the value of sorghum supplied to market by 205.5449 birr. This was eventually expected since households who have greater production have more surpluses they can sell. The findings of this study is consistent with that of Martey et al., (2012) that households with higher value of crop produced sell higher proportion of their produce. 
Table 3.3 Tobit Model Results for Factors Influencing the Level/Extent of Market Participation

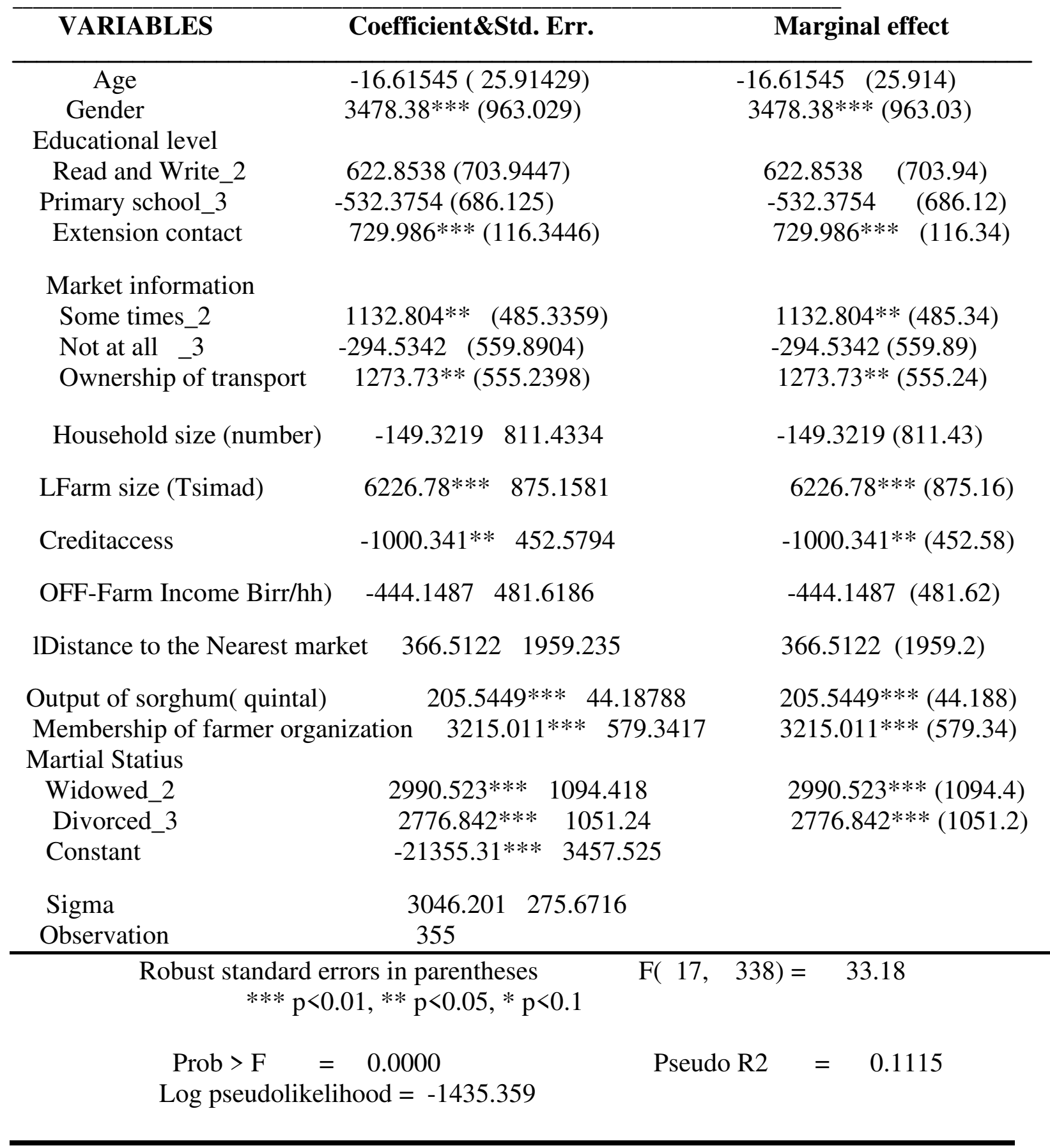

Obs. summary: 209 left-censored observations at value $<=0$

146 uncensored observations

0 right-censored observations

Source: Own Survey Data (2010/11) 


\section{SUMMARY, CONCLUSIONS AND POLICY IMPLICATIONS}

\subsection{SUMMARY}

This study aimed at identifies the major factors on market participation of smallholder sorghum producer in Moretna jiru district. In order to examine determinants of commertalization of smallholder sorghum crop producers, descriptive statistics and probit and Tobit models were employed. During analysis, Stata software's were used. The result indicated that the decision to participate in the sorghum market is significantly determined by output of sorghum, ownership of transport and farm size positively. However, access to credit negatively affects the participation of small holder sorghum producers. The intensity of market participation on sorghum output is significantly determined by the output of sorghum, farm size and ownership of transport.

Based on the survey data analysis result the researcher motivated to give some advice for the smallholder farmers those who benefited from The amount of sorghum produced positively influenced market participation decision and extent of market participation. Hence, policies that would improve farmers" sorghum production capacity such as supply of improved seeds and credit to farmers should be explored.

The study was undertaken with the objectives of identifying the determinants of participation and level of participation of the households' in sorghum output marketing in Moretna Jiru District. In order to select the sample households, a two stage sampling procedure was followed. In the first stage maize growing kebeles were identified in collaboration with the District's Agricultural office from which three kebeles were selected randomly. Then from the selected three kebeles 355 households were selected randomly based on probability proportionate to size of the kebeles' number of households. From this sample primary data was collected using semi structured questionnaire and secondary data was collected from District agricultural office and Research Centers and published documents.

Descriptive statistics showed that there was significant mean difference between sorghum output market participant households and non-participant households in the following parameters. These were, from demographic characteristics, age and sex of the household head, family size and educational status of the household head. And from socioeconomic and institutional 
characteristics, distance to the nearby agricultural service center, distance to the nearest market center, land holding size and land allocated for sorghum show significant difference. There was a significant mean difference between participants and non-participants in maize production.

Results of the probit model depict that eight out of 15 variables included in the analysis were found to affect households' decision to participate in the sorghum output market significantly. These were, output, extension contact, farm size, membership of farmer group and ownership of transport which are found to affect households' Decision to participate in sorghum output market positively and significantly; whereas household size, credit access and off-farm income was found to affect the same decision negatively and significantly.

In the Tobit model eight variables out of 14 variables were found to significantly affect the intensity of value of sorghum marketing. These were, sex of the household head (being male), household size and land holding were found to affect the intensity of volume of maize output market by the households' positively and significantly; whereas, distance to the nearest market was found to negatively and significantly affect intensity of participation of the households in maize output market. Land holding was found to affect both households' decision to participate in maize market and intensity of participation; so it was observed as a crosscutting variable.

\subsection{Conclusions and Recommendations}

From the study it was found that different demographic, socioeconomic and institutional factors inhibited most of the farmers to participate in sorghum marketing and to increase their level of participation.

The econometric results showed that output of sorghum, extension contact and farm size positively and significantly affected households' decision to participate in sorghum marketing. This showed that extension contact is a key to the farmers' commercialization since it increases the knowledge and skill of the farmers regarding how to apply different agricultural technology that increase the productivity of sorghum crop. So the government should give batter focus on assigning trained agricultural experts in each sorghum crop growing kebeles.

In the Tobit censored regression result extension contact, gender, output, farm size and member of farmer group were significant factors that affect the value of sorghum sold. That shows male 
households have sold large proportion of their sorghum produced compared to female household heads. Therefore it will be good if policies strengthen the support being given to the female headed households using different methods like by increasing their awareness through affirmative actions, by increasing their participation in different institutions and support them to engage in cooperatives.

Farm size was a crosscutting variable which affects both the decision and intensity of sorghum marketing in the district. It will be difficult for policy makers to increase the land holding of the household; but the policies need to strengthen more in intensifying the farm practices through provision of sustainable and timely availability of inputs, increasing the farmers' awareness on production packages like agronomic practices and proper application of inputs. This will enable the farmer to produce more from the same plot of land so that increased participation and intensity of sorghum market participation will be achieved

\section{Data Availability}

The datasets used to support this study are available from the corresponding author upon reasonable request.

\section{Competing interest}

I declare and affirm that this paper is my own work. I have followed all ethical and technical principles of scholarship in the preparation, data collection, data analysis and compilation of this paper. Any scholarly matter that is included in the thesis has been given recognition through citation, therefore there was no competing.

\section{Funding}

There was no funding support during this study.

\section{Author Contribution}

All researches in this study were full contributed in manuscript and methodology development, data collection and analysis part of the study.

\section{Acknowledgment}

Thanks to all economics department academic staff, third year undergraduate economics students and the research and community service vise-president of Samara University. 


\section{REFERENCE}

CSA (2015). Total Population censes data of Moretna jiru district.

Demeke M., Di Marcantonio F., 2013. Analysis of incentives and disincentives for sorghum in Ethiopia. Technical notes series, MAFAP, FAO, and Rome.

Egbetokun, A., \& Omonona, B. T. (2012). Determinants of Farmers' Participation in Food Market in Ogun State. Global Journal of Science Frontier Research Agriculture and Veterinary Sciences, 12(9), Version 1.

Gujarati, D. (2004). Basic Econometrics, Fourth Edition. New York: McGraw-Hill.

IFAD. (2011). Rural poverty report. International Fund for Agricultural Development.

Kinfe, H., \& Tesfaye, A. (2018). Yield performance and adoption of released Sorghum varieties in Ethiopia. Edelweiss Applied Science and Technology, 2(1), 46-55. 
Maddala, G.S, (1983). Limited Dependent and Qualitative Variables in Econometrics. Cambridge University Press.

Martey, E., Al-hassan, R. M. and Kuwornu, J. K. M. (2012). Commercialization of smallholder agriculture in Ghana a Tobit regression analysis. African Journal of Agricultural Research, 7(14), 2131-2141.

Mather,D., Boughton, D., and Jayne T.S., (2011). Smallholder Heterogeneity and Maize Market Participation in Southern and Eastern Africa: Implications for Investment Strategies to Increase Marketed Food Staple Supply: MSU International Development, Working Paper

Mekonnen Demeke and Di Marcantonio, F. (2013). Analysis of Incentives and Disincentives for Sorghum in Ethiopia. Technical notes series, MAFAP, FAO, and Rome.

Ministry of Finance and Economic Development (2010). Growth and Transformation Plan Annual Progress Report for F.Y. 2009/10. Addis Ababa, Ethiopia.

Ministry of Finance and Economic Development (2012). Growth and Transformation Plan Annual Progress Report for F.Y. 2010/11. Addis Ababa, Ethiopia.

MoARD (Ministry of Agriculture and Rural Development), 2010. Ethiopia's Agricultural and Sector Policy and Investment Framework (PIF): 2010-2020, Addis Ababa, Ethiopia.

MoFED (Ministry of Finance and Economic Development). (2006). A plan for Accelerated and Sustained Development to End Poverty (PASDEP). Addis Ababa.

Mussema, M., and Dawit, A. (2012). Red pepper marketing in Siltie and Alaba in SNNPRS of Ethiopia: factors affecting households' marketed pepper. International Research Journal

Olani Nagara, G. (2017). Genetic Diversity Analysis of Sorghum [Sorghum bicolor (L.) Moench] Races in Ethiopia Using SSR Markers (Doctoral dissertation, Addis Ababa University).

Pender, J. and Dawit, Alemu, 2007. Determinants of Smallholder Commercialization of Food Crops: Theory and Evidence from Ethiopia. Discussion Paper No. 75. IFPRI (International Food Policy Research Institute), Washington, DC, USA. 
Tesfaye, E. (2013). Adoption of improved sorghum varieties and farmers'varietal trait preference in kobo district, north Wolo zone, Ethiopia (Doctoral dissertation, MSc. Thesis, Haramaya University, Ethiopia.

Tesfaye, K. (2017). Genetic diversity study of sorghum (Sorghum bicolor (L.) Moenc) genotypes, Ethiopia. Acta Universitatis Sapientiae, Agriculture and Environment, 9(1), 44-54.

Tobin, J. (1958). Estimation of relationships for limited dependent variables. Econometrica: journal of the Econometric Society, 24-36.

Wooldridge, J. M. (2002). Econometric Analysis of Cross Section and Panel Data. Massachusetts Institute of Technology, Cambridge, Massachusetts, London, England.

World Bank, (2007). "Agriculture for Development". World Development Report 2008. Washington: World Bank.

Yamane, I., \& Sato, K. (1967). Effect of temperature on the decomposition of organic substances in flooded soil. Soil Science and Plant Nutrition, 13(4), 94-100. 
Figures

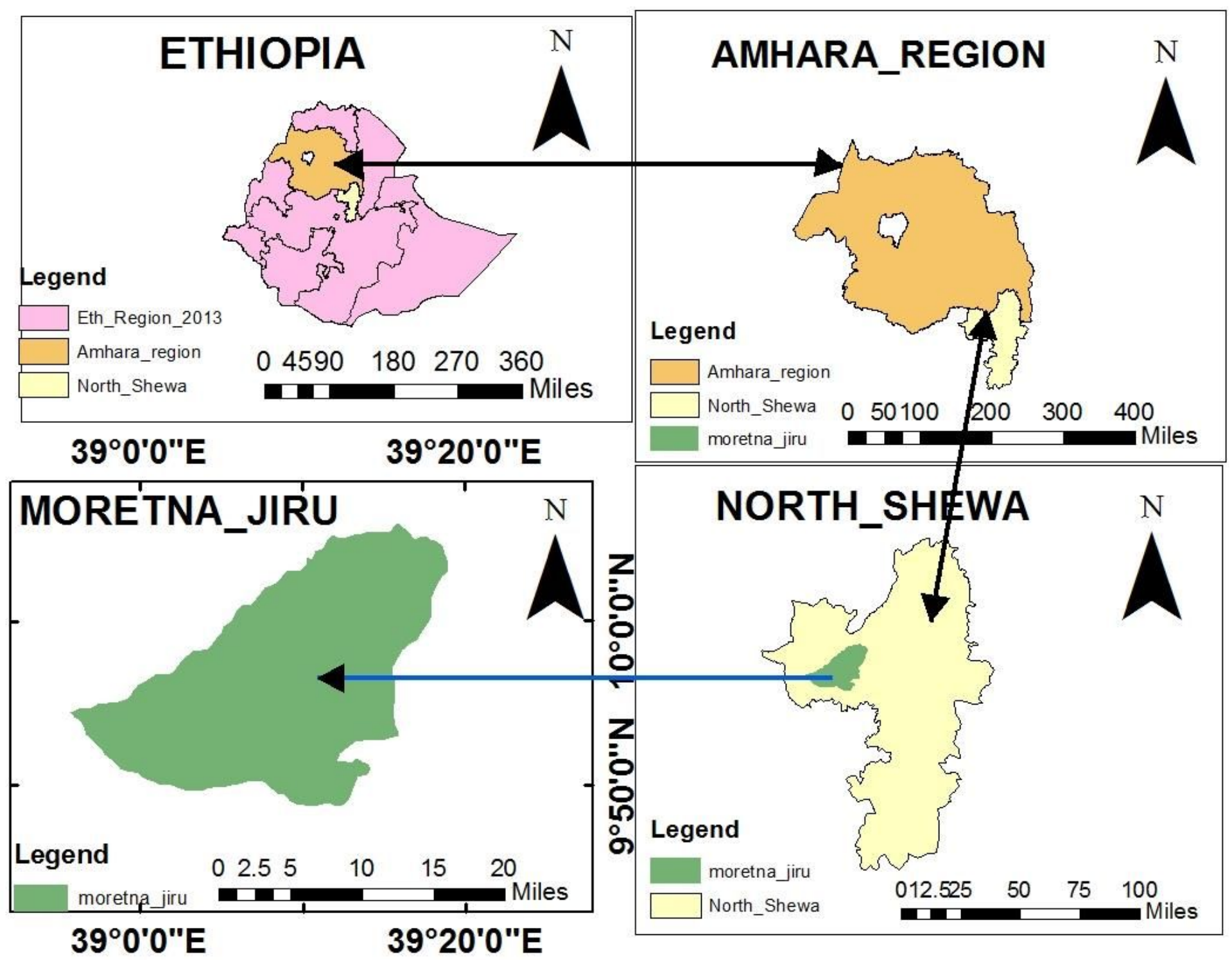

Figure 1

Map of The Study Area (Moretna jiru District) Data Source: MJDAO (2011) Note: The designations employed and the presentation of the material on this map do not imply the expression of any opinion whatsoever on the part of Research Square concerning the legal status of any country, territory, city or area or of its authorities, or concerning the delimitation of its frontiers or boundaries. This map has been provided by the authors. 


\section{Source of Market Information}

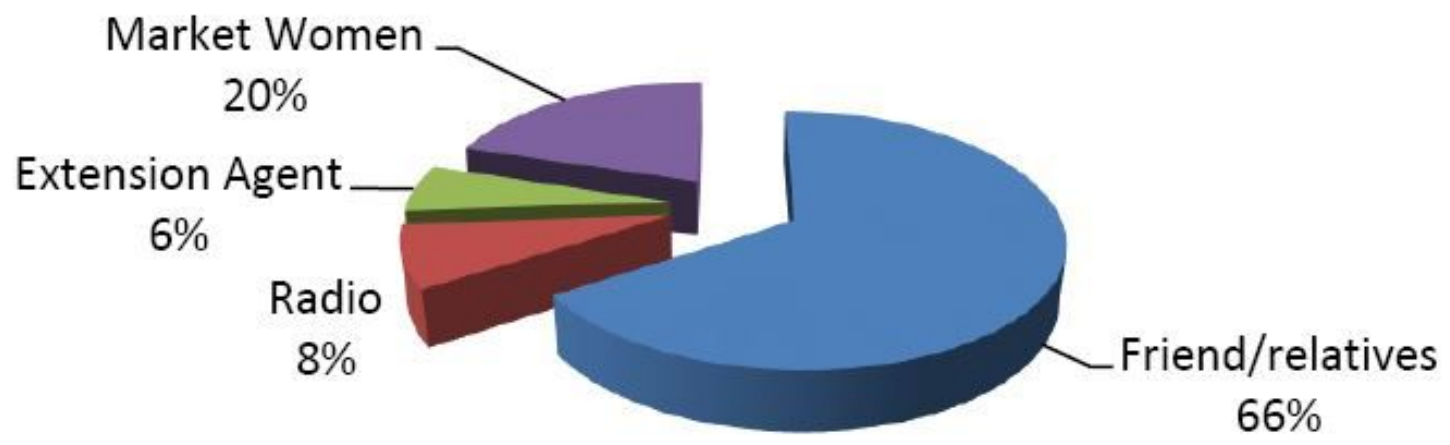

Figure 2

Source of Market Information. Source: Survey Data (2010/11) 